\title{
Mishaps In/Front of the Iron Horse: A Social History of Train Accidents in Madras Presidency (1881-1891)
}

\author{
JINEESH P S* \\ Assistant Professor of History Department of History, Govt. College, Madappally, Vadakara-Kozhikode, \\ Kerala-673102.
}

*Corresponding Author: JINEESH P S, Assistant Professor of History Department of History, Govt. College, Madappally, Vadakara-Kozhikode, Kerala-673102.

\begin{abstract}
This paper looks at the social history of train accidents in Madras Presidency during 1881 and 1891. There was a public imagination of train as a single-eyed, smoke spitting, 'howling demon', which later became real demon in the lives of the Indians. The origin and development of railways in India is a hot topic for historians and social scientists. The emergence of railways in Indian sub-continent has been viewed as the extension British capitalist ventures. It is further viewed as a part of integrating India to the British colonial empire. Primarily based on administrative reports of Railways of Madras Presidency, the paper seeks to look at the social history of train accidents in Madras presidency. The colonial masters in their urge to maximize profit, did not make essential protective measures at the workspace. The result was the accidental death of poor labourers. Similarly, the train and rail lines were identified as one of the modes of committing suicides. Poor village folk, having fed up with agrarian loss and famines and even diseases sought their solace in the rail tracks. No measures were taken by the British to prevent such mishaps.
\end{abstract}

Key words: Colonial Madras, capital, railroads, mishaps, injuries, suicides.

\section{INTRODUCTION}

The basic trait of human beings is to move around, and they always hesitate to remain at a specified place for long time. They prefer to roam around and explored the unknown environment in their vicinity and beyond. They strolled over the land and later devised certain techniques and innovations that could help them to move faster to long distances. The wheelswhich eased the potters' work later became the most important tool that could ensure speed to their mobility. The development of various transportation modalities, all though the ages, could be seen in this context. Like the invention of wheel, the use of steam power had also transformed the human quest for rapid and effective methods for moving vehicles. Though steam driven devices had existed even in $1^{\text {st }}$ century AD, the first commercially used device came into vogue only in 1698 whenan English engineer Thomas Savery invented 'engine'. As it was a big boon to the miners in their work, it was called as 'miners' friend'. It was a pump, worked by using steam power, to create a vacuum to draw water from flooded mines and it was of great help to the miners.

The 'revolutionary effect' of steam was soon extended to railway. It is noted that "in September 1830, just fifteen years after the Battle of Waterloo, the inaugural train chugged along the tracks at the opening of the Liverpool \& Manchester Railway"1. There were serious discussions in the administrative circles of Britain to extend the benefits of new power sources to the colonies. India, being the 'jewel on the British crown', had come to the minds of the British administrators as the place where they would introduce railway in the first stage itself. It is stated that "iron and steam has civilized mankind, let's give India, the benefit of that discovery" ${ }^{2}$. The emergence of railway in India

\footnotetext{
${ }^{1}$ Christian Woolmer. (2009).Blood, Iron \& Gold: How the Railways Transformed the World, Atlantic Books, London, ,p.41.

2 Pamphlet addressed to the Secretary of State for India, 1853, in Home Correspondence 'B', copies of letters sent, 1849-1879, L/PWD/2/68, OICC, Cited in Aparajita Mukhopadhyay, Imperial Technology and Native Agency: A Social History of Railways in Colonial India, 1850-1920,Routledge, 2018, p.2.
} 

1891)

should be seen in this techno-historical context. Railway has been identified as one of the "big technologies" that the British had introduced in India ${ }^{3}$. The introduction of railways made India into a connected space and the expansion of it during the British colonial period was quite wondering. Several studies have already been made on the impact of railways on India ${ }^{4}$. But none of them have turned into the grime side of the story. In this paper an attempt is being made to look at social history of the train accidents in Madras Presidency during the period from 1881 to 1891.

\section{MAKING OF THE 'INDIAN IRON HORSE'}

Though the capitalist and commercial interests, that were dominant in Britain had rigorously advocated for the immediate implementation of railways in India, still some sceptic minds had pulled back that move. The ambivalence of the imperial British state had resulted in lagging of railway projects in India. The process was sped up when Lord Dalhousie got appointed as Governor General of India in 1848. He has been alluded as the 'architect of Indian railway system's. Along with him there were some other noted faces who had frequently put pressure on the imperial state for the realisation of proposed railway projects in India. It is stated that "the pioneer of the Indian railroad development was Rowland Macdonald Stephenson, a railroad engineer and a visionary who dreamed of laying tracks from Europe to India and to China"6. The colonial railway and the related developments have brought all-encompassing changes in India. "Visitors to India in January of 1850 encountered a fascinating and complicated world within railroads had no place"". It was that Indian world got transformed substantially due to the British initiatives in railway since the second half of the $19^{\text {th }}$ century.

At this context it would be interesting to look at the motivating factors for the introduction of railway in India. It is opined that "the prime motivating force behind the introduction of the railway system in Bombay was the need to transport cotton, on which the city's economy depended, the same product which had stimulated the creation of the Liverpool and Manchester. The failure of the American cotton crop in 1846 pushed the cloth manufactures in Manchester and Glasgow to seek new sources of the material such as India" ${ }^{\prime 8}$. The Industrial Revolution in England and subsequent developments had required a historical condition where one could ensure the easy mobility of raw materials and finished goods. Industrial Revolution had contributed much to the strengthening of capitalism and vice versa. "Railway in India, from the first accounts of its history, has been described as a vector of capitalist modernity" ${ }^{9}$ For that matter, Indian railway was conceived as their important project by the British. "Building the railroad system of India became the most monumental project of the colonial era; it involved the largest capital inflow of the nineteenth century and produced the fourth largest rail network on earth, behind only those of the United States, Canada and Russia"10.

The opening of Bombay-Thana line was on 16 April 1853 and The Illustrated London News had reported the incident as an important one. That epoch making event would be remembered far longer than the recent battles which had brought India into the British empire. "Newspaper accounts describe a fourteen-carriage train pulled by three engines transporting some 400 people on a day designated as public holiday"11. The incident was marked as a significant one in Indian history. The train of fourteen carriages carrying all VIPs was sent off by twenty-one gun salutes. "The crowd, many of

\footnotetext{
${ }^{3}$ David Arnold. (2013).Everyday Technology: Machines and the Making of India's Modernity, The University of Chicago Press, Chicago and London, , p.150.

${ }^{4}$ SeeIan J Kerr. (1997).Building the Railways of the Raj 1850-1900, Oxford University Press, Calcutta, Amba Prasad. (1960). Indian Railways, Asia Publishing House, New Delhi, M Robbins. (1962). The Railway Age, George Allen and Unwin Ltd., New Delhi, Christian Woolmer, Op.Cit.

${ }^{5}$ A Sreedhara Menon. (1989). Modern India Since 1907 and History of the Freedom Movement, Thiruvananthapuram, p.227.

${ }^{6}$ Daniel R Headrick. (1981).The Tools of Empire: Technology and European Imperialism in the Nineteenth Century, Oxford University Press, New York and Oxford, , p.183.

${ }^{7}$ Ian J Kerr. (2007).Engines of Change: The Railroads That Made India, Praeger Publishers, London, , p.1.

${ }^{8}$ Christian Woolmer, Op.Cit.,p.90.

${ }^{9}$ Laura Bear, Op.Cit., p.1.

${ }^{10}$ Daniel R Headrick, Op.cit., p.181.

${ }^{11}$ Ian J Kerr, Op.Cit., p.6.
} 
whom had perched on walls or climbed trees to get a better view, were all the more impressed because of the sheer scale of the first train"12. The enthusiasm shown by the Indians and the high demand of Indian raw materials in Britain had motivated them to intensify the extension of railway construction in India. There was substantial progress in the quantity of railway within a short span of time. It is noted that "by 1872, India had over 5000 miles of track" ${ }^{13}$ which could be more than 8000 kilometres. By 1902, British India (consisted of today's India, Pakistan, Bangladesh and Burma) had 25,936 miles, which came around 41800 kilometres, more than the rest of Asia put together, over three times as much as Africa and more both in total and per capita than Japan ${ }^{14}$. Along with their vested colonial and capitalist interests, the British reported to have shown interest in extending railway to ensure essential foodstuffs to meet the famine situation. "The devastating famine that hit vast swathes of southern and western India in 1876-78, causing millions of deaths and the Famine Commission whose report followed in 1880, directed renewed attention to the question of improvement" ${ }^{\prime 15}$. It directed to ensure connectivity to the hinterland of the Presidency to reach out during catastrophes.

\section{The MADIRASI VERSION: MOVING ON IRON RODES}

Across India, the British had materialized the dream of railway through forming and acting of railway companies. In south India, this responsibility was primarily done by Madras Railway Company. Though initial steps towards this direction were made in 1830-31, substantial progress was made only in 1836. In the year A P Cotton, a civil engineer of Madras,prepared a lengthy and serious report on the railway development of Madras. He conceived and proposed a railway line in Madras Presidency from Madras to Bombay via Bangalore and Pune. Similar discussion and lobbying were done in Britain as well. The culmination of this process was the formation of Madras Railway Company on 8 July 1845. The stated objective of the Company was the construction of railroads in Madras Presidency. But still, the Company had faced apathetic attitude from the authorities in Britain. To transcend such attitudes, there were attempts even from the Madras public to put pressure on the authorities in Britain to accord sanction to railway projects ${ }^{16}$. Though the imperial government had given some liberal assistance to the railway developments in Calcutta, and Bombay, it lacked in Madras. But finally, some assistance was sanctioned for railway from Madras to Walajah Road $(\text { Arcot })^{17}$. In Madras, two railway companies-Madras Railway Company and South Indian Railway Company (both were 'guaranteed companies')-had their lines almost entirely within the Presidency ${ }^{18}$. Guarantee system was the most popular system of railway construction in India as per it and Companies had undertaken the construction activities. It is stated that "through the instrumentality of Companies, who receive from the Government, the guarantee of a certain rate of interest upon the capital expended with the approval of Government,upon their undertakings" ${ }^{\text {"19 }}$. The construction of Madras railway was commenced on the 9 June $1853^{20}$.

In the construction of Madras railway, Lord Dalhousie's plan was implemented. He suggested to have two lines with Madras as the origin point. The two lines he proposed were: 1. Madras via Wallajah Road (Arcot), Vellore, Salem and onward to Western coast with branch to Bangalore and to the foot of Nilgiris. 2. From Madras through Cuddapah district to Bellary to Bombay ${ }^{21}$. The construction of the first line was commenced on the 9 June 1853 and on 1 July 1856 the first railway line in South India had started operation from Royapuram to Walajapet or present Wallajah Road. By 1871, the Madras Railway Company could extend to Raichur on the Madras-Bombay route. Within its 35 years, substantial progress was made by the Madras railway. Impact of railway in shaping the destinies of Indian lives have been amply studied. Railway was an experiment with

\footnotetext{
${ }^{12}$ Christian Woolmer, Op.Cit.,p.94.

${ }^{13}$ Daniel R Headrick, Op.Cit., p.186.

${ }^{14}$ Ibid., p. 187.

${ }^{15}$ David Arnold, Op.Cit., p.27.

${ }^{16}$ Manual of Administration-Madras Presidency-M/12, Preserved at Regional Archives, Kozhikode, p.420.

${ }^{17}$ G O No.1853 dated 28 November 1848, Public Works Department, Tamilnadu State Archives, p.6.

${ }^{18}$ Manual of Administration-Madras Presidency-M/12-Kept at Regional Archives, Kozhikode, p.426.

${ }^{19}$ Juland Danvers, Report to the Secretary of State For India In Council On Railways In India to the end of the year 1859, 1860. Accessed from www.google.com.au/books., p.5.

${ }^{20}$ Ibid., p.427.

${ }^{21}$ G S Khosla. (1988).A History of Indian Railway, Govt. of India Publication, New Delhi, , p.169.
} 
multi-dimensional impacts. The impact of railway was not limited to economic field alone. It had impact on society, culture and even in political practices. It radically altered the perceptions of time and space ${ }^{22}$. Railways have been identified as $19^{\text {th }}$ century cultural ideas of progress. To some others, "railways were mesmerizing because they appeared to materialize individual liberty and social progress, but ultimately this promise wasn't realized in India or elsewhere" ${ }^{, 23}$. But none of these studies have attempted to look at the departed human souls and people with wounds and tears due to train related mishaps. Our attempt here is to engage the social history train accidents in Madras from 1881 to 1891.

\section{SWALlOWED BY 'Single-Eyed Demons': ON Train ACCIDENTS}

When we look at the statistics of accidents happened in the Madras Province from 1881 to 1891, they could be broadly categorized into three as 1) Operational mishaps, 2) Accidents due to public negligence and 3) Loss of railway property and infrastructure due to natural calamities ${ }^{24}$. Most of those accidents were of operational in nature. They could be described as accidents or troubles happened due to the plying of trains in Madras Presidency. Collisions, derailments, unmanned gates, obstructions on railway lines, defects on train wheels, damaged lines, fires in train etc., are the important accidents in the first category. In the second category, there were several instances in trains hit the bullock bandy while they were crossing the railway lines. The cattle were being hit by the running trains. There were several instances of trains running over the cattle and that was the category of train mishaps which had taken maxim death tolls in the Madras Presidency. In the third category, we can see the loss to the railway stations' infrastructure due to monsoon related climatic changes like cyclones, winds, rain etc.

1) Operational Mishaps:

In the Madras Presidency, there were 30 derailments in 1881 itself $^{25}$ and it was a high figure regarding the extend of rail line during that period. Fires in train came next in the category of operational mishaps as it was 22 in number. The number of collisions, accidents at unmanned gates and defects to the train wheels came as 2,11 and 1respectively ${ }^{26}$. The condition was not different in the year to come. In 1882 derailments were somewhat reduced to 28 and so was the case of accidents at unmanned gates. It reduced to 9. Contrary to 1881, the number of collisions got enhanced to 3 . The alarming case was the fire in the train as it increased to 36 , though it was 22 in $1881^{27}$. Due to the absent mindedness of the persons employed, Vellore station had witnessed a serious accident. "On the $31^{\text {st }}$ May 1883 the mail train collided with an extra goods train standing Vellore station, owing to the pointsman turning the former on to the main line instead of into the platform siding. Three vehicles of the goods train were derailed, and six passengers were slightly injured ${ }^{28}$. Unlike the previous year, there was sharp decrease of fires in trains in 1883 . "In one of these cases a horse andox, together with the ponies in it were completely burned and the third animal was severely injured and that it dies subsequently"29. It makes clear that not only the human beings, the animals, which were carried in the trains, too had killed in the accidents.

There were instances of derailments due to the carelessness of the staff employed in the railway. It is noted that a collision occurred at Guntakal station on 16August 1884 and in it seven passengers received slight injuries. This accident was due to a stiff coupling (G I P) which allowed some loaded wagons, which were being shunted, to become detached and to run back on to passenger vehicles

\footnotetext{
${ }^{22}$ Ritika Prasad,Time Sense: Railways and Temporality in Colonial India, in Modern Asian Studies (MAS), Vol.47, Issue4, July 2013, pp.1252-1282.

${ }^{23}$ Laura Bear, Op.Cit., p.4.

${ }^{24}$ Administration Report of the Public Works Department-Railway Branch-in the Madras Presidency for the year 1883-84, (A 1272), Preserved at Regional Archives, Kozhikode (RAK), p. 7.

${ }^{25}$ Ibid.,p. 7.

${ }^{26}$ Ibid., p. 7.

${ }^{27}$ Ibid., p. 7

${ }^{28}$ Ibid., p. 7

${ }^{29}$ Ibid., p.7
} 
standing at the stations ${ }^{30}$. At Arakonam too, a notable accident occurred. Two passengers and four servants of the Railway Company were slightly injured in a derailment at Arakonam on 27 October $1884 " 31$. "The only accident of a serious nature, but which was fortunately not attended with any disastrous results, was the derailment of the mail train near Cuddapah station at 1.40 am on the 29 April 1885. The accident was due to the malicious removal of the fishplates and keys from one rail, which caused the tender and eleven vehicles to leave the rails. A plate-layer was convicted and sentenced to seven years' penal servitude by the Sessions Judge as having perpetrated the crime, but on appeal to the High Court the conviction was set aside"32. The faults from the railway employees were dealt with punishments, which usually set aside by the higher courts.

In the year 1887, there were no serious accidents to trains. But there was a sharp increase in derailments, which was counted to 40. Eight passengers were slightly injured in a derailment at Jalarpet. Such instances of derailments were happened due to the carelessness of pointsmen ${ }^{33}$. One must seriously think of why there was increased number of derailments. The official records do assign the responsibility upon the petty employees like pointsmen. But how such petty officers alone could be responsible for the derailments? What was their supervisory officers doing then? So, it could be argued that the petty officers like pointsmen were made as scapegoats for saving the face of the top officials. In 1887, there were certain other instances of operational havocs. The passenger killed for want of caution was a child who fell out of train while in motion. The servant of the Company killed from causes beyond his own control was a cooly, who was drowned by the sudden sinking of one of the cylinders of the new Pennar bridge ${ }^{34}$. Here again we can find the absence of proper measures to ensure safety of the coolies in the Company's service.

In 1888, there were no serious accidents to trains, but the total number of accidents is higher than in the year preceded. It was a consequence of increase in the number of derailments. Now the Company was ready to initiate an enquiry on the frequent occurrences of derailments in Madras Presidency and it is evident that they took nearly thirty plus years to undertake such a serious study. A special committee was convened to inquire into this, and has submitted a report advocating, among other measures, improved switch gear and points as well as the grouping of switch levers at large stations ${ }^{35}$. It shows how much apathetic the British were in dealing with the derailments and the consequent sufferings to the people, at large, in Madras presidency ${ }^{36}$. Because of the large number of derailments and on the recommendations of a committee of Railway officers, the appointment of Inspector of Points and Crossings has been resuscitated" ${ }^{37}$.

But such reports did not bring any positive impact on the functioning of railway. The recommendations of the committee were not implemented in true spirit. The result was the occurrence of derailments in future. It is reported that "what might have been a serious accident occurred at Jalarpet during shunting on $1^{\text {st }}$ April 1889, when twenty-eight wagons ran out of the station for a distance of 16 miles. The pointsman, instead of turning the wagons on to the catch siding, set the points for the main line. The wagons were eventually arrested by a reverse gradient" ${ }^{\prime 3}$. Similarly, "on $19^{\text {th }}$ September the North-west line mail to Madras, when leaving Puttur station, collided with the rear vehicles of an extra train which stood fouling the points. Three wagons and the guard's van of the extra train and the engine of the mail were derailed. No injury was sustained by the

\footnotetext{
${ }^{30}$ Administration Report of the Public Works Department-Railway Branch-in the Madras Presidency for the year 1884-85, (A 1273), Preserved at RAK, p. 8.

${ }^{31}$ Ibid., p. 8

${ }^{32}$ Administration Report of the Public Works Department-Railway Branch-in the Madras Presidency for the year 1887-88, (A 1276), Preserved at RAK, p. 4.

${ }^{33}$ Ibid., p. 10 .

${ }^{34}$ Ibid., p. 10.

${ }^{35}$ Administration Report of the Public Works Department-Railway Branch-in the Madras Presidency for the year 1888-89, (A 1277), Preserved at RAK, p. 10.

${ }^{36}$ Ibid., p. 10 .

${ }^{37}$ Administration Report of the Public Works Department-Railway Branch-in the Madras Presidency for the year 1889-90, (A 1278), Preserved at RAK, p. 10.

${ }^{38}$ Ibid., p.10.
} 
passengers, but the derailed vehicles were somewhat damaged" ${ }^{39}$. Carelessness of the employees in charge of railway lines always created problems. Why was it happened? Was it due to the absence of proper training to them? Or due to absence of proper penal provisions for those who were careless in doing their responsibilities? The authorities were driven by the single aim of making profit and much as they could, even by providing proper training to the workers.

Along with derailments, clashes between trains were also quite common those days. Officially it was reported that "on the $9^{\text {th }}$ January a collision occurred at Vangamaur station between two mixed trains owing to a breach of rules on the part of the Assistant Station Master and pointsman. No one was hurt, but cow-hatchers and buffers of the engine and the head stocks and couplings of four goods vehicles were damaged. The assistant station master and pointsman were prosecuted and the former was acquitted, the latter was sentenced to six months simple imprisonment. Situation became thickened when punishments to some employees who were not vigilant in executing their responsibilities began to appear the scene.

Derailments and collisions were substantially reduced, though not completely wiped out. On 13 May 1891 at Palghat station, the engine of the local train and one wagon were derailed and travelled 215 feet on the ballast, the rest of the train remaining on the rails. Considerable damage was caused to the permanent way. The accident was attributed to a slight defect in the points (subsequently remedied) and the excessive speed at which the train was travelling ${ }^{40}$. Likewise, on 7 August of the same year a slight collision occurred at Jalarpet station, the pointsman having, contrary to instructions, allowed the mail train from Madras to run on to the platform siding (where the mail train from Calicut was standing) instead of on to the main line. No one was injured; the cow-hatchers and buffers of both engines were damaged. On the 16 November a light engine passed the distant signal while at danger and collided with the break-van of the pilot train which was standing at Veyasarpaudy junction and on the rear of which the usual lights were not shown. No one was hurt. Considerable damage was done to nine wagons" $"$.

2) Accidents due to public negligence:

In Madras Presidency, people had used bullock bandy for the transportation of goods and people. It is reported that "the number of gates run through is usually large and in most cases the gate-keepers were in fault. One servant of the Company was injured by the engine of a special train running into a bullock bandy at a level-crossing" 42 . The clash of bullock bandy and train could be taken as the encounter of traditionality versus modernity. There was a sharp increase in the train running over the cattle. 1n 1881, the total cases of clash between bullock bandy and train were 59 and in 1891 it rose to 116. Similarly, due to public negligence, there were certain other instances of accidents in the Madras Presidency. AtRenigunta station, for instance, some derelict wagons came into collision with a trolly which was being pushed by a gang cooly who was killed" ${ }^{\prime 3}$. In another incident, two personsbullock bandy driver and a woman- killed at level-crossings. The driver was attempting to cross the level-crossing when the mail train was approaching, and the woman was trying to cross the line on the Rayapuram branch in front of a material trunk in motion ${ }^{44}$. It is surmised that the British, might not made mandatory measures like precautionary hoardings and warning instructions, in the rail track premises.

3) Loss of railway property and infrastructure due to natural calamities:

In the Madras Presidency, the monsoons and the related climatic changes brought serious destruction to the upbuilding railway infrastructure. Monsoon, cyclone, wind, floods etc., resulted mass scale destruction of men and material to the railway in Madras Presidency. Several instances of destruction

\footnotetext{
${ }^{39}$ Administration Report of the Public Works Department-Railway Branch-in the Madras Presidency for the year 1890-91, (A 1279), Preserved at RAK, p. 11.

${ }^{40}$ Administration Report of the Public Works Department-Railway Branch-in the Madras Presidency for the year 1891-92, (A 1280), Preserved at RAK, p. 9.

${ }^{41}$ Ibid., p.9.

${ }^{42}$ Administration Report of the Public Works Department-Railway Branch-in the Madras Presidency for the year 1885-86, (A 1274), Preserved at RAK, p. 8.

${ }^{43}$ Ibid.,p. 8

${ }^{44}$ Ibid.,p. 9
} 

1891)

of railway property could be found in Madras. In 1883 "the roof of the goods shed and one end of the station verandah at Kuppam were thrown off by high wind" ${ }^{\prime 4}$. Similarly, the cyclone of 31 October 1888 caused three breaches in the $61^{\text {st }}$ mile, south west line, between Sholinghur and Arcot, owing to the bursting of the Tallingay tank, but through traffic was resumed on the $5^{\text {th }}$ November. Slight damage occurred at mileage S5/2 near Vellore and in the $202^{\text {nd }}$ mile, North-West line; slips happened near Munnal on South-West line, but these were repaired without interrupting traffic ${ }^{46}$. Here we can see how the traffic was being suffered by the natural calamities.

The unpredicted nature of the natural calamities had brought devastation to the railway lines and related infrastructure in Madras presidency. One such instance could be found in 1889 . "On $16^{\text {th }}$ October 1889 cyclone crossed the northern portion of the Madras Railway which was damaged in five places by the severe floods resulting from the heavy rainfall bursting many tanks. The overfilling and ultimate breaching of the Rayalcheru tank scoured the railway embankment and washed away ballast and pitching at miles 239/12 and 244/4 and 5. The injury was completely alright, and traffic was quickly resumed. Two hundred and sixty lineal feet of ballast were washed away at mile 266/11 to 13 where the transverse the Pattachottacheru tank; the embankment was in places scoured to a depth of 5 feet $^{47}$.

Some instances of narrow escape of railway infrastructure from destruction due to monsoon related climatic changes could also be found in Madras presidency. A bridge of 5 spans of 30 feet at mile $257 / 14$, just beyond the north points of the Gooty station, narrowly escaped being washed away. The water rose to within 3 inches of the underside of the girders and scoured away the backing of the south abutment on both sides, leaving the bank nearly vertical and the wing walls quite exposed. On both approaches the bank on the downstream side was washed away to within a couple of feet so of the rails. The upstream side of the bank also suffered, but as the bridge was constructed for a double line, there was 9 feet width of bank clear of the rails left standing.

Natural calamities again had a devastating effect on the ongoing railway projects in Madras Presidency. The unflooded bridge of 4 openings of 64 feet composed of two continuous girders at mile 258/10 was partially wrecked. The flood rose to one foot below the bottom of the girders. The set of the current was apparently against the south abutment, the bank behind it being entirely washed away and the abutment itself undermined, so that it sank bodily 7 or 8 feet, and partially fell over, obliquely to the line. The pier next to the abutment was scoured and washed bodily away. The bridge was temporarily repaired and traffic at caution speed was restored four days after the accident. The geography and climate of South India had been frequently disturbed or hampered the construction process of railway in Madras presidency.

There were changes in the magnitude of natural calamities and their impact on railway under construction. It is interesting to note that "the other natural obstacle was the great rivers of India which frequently brought devastating floods" considerable damage from exceptionally heavy rains and floods between miles 309 and 344 on the $28^{\text {th }}$ and $29^{\text {th }}$ October 1890. At mile 311 the flood topped the line, covering the rails with 3 feet of sand. At several other places the water rose over the line washing away ballast and small portion of embankment. At mileage 343/6-8 mileage four chains of bank, 9 to 12 feet in height were carried away. At 343/6-8 mileage six and half chains of bank were breached, leaving gaps, one 140 feet long and 12 feet deep, and one 100 feet long and 6 feet deep. Traffic was resumed four days after the occurrence of the accident. It is also significant that the Palghat branch was at the same time badly injured in several places, the bank being completely washed away in four places, leaving gaps from 75 to 160 feet in length and 9 to 15 feet in depth. At the Koilpatti branch the water rose to rail level, 19 feet to 6 inches over the highest recorded flood. The bridge, however, sustained no serious

\footnotetext{
${ }^{45}$ Administration Report of the Public Works Department-Railway Branch-in the Madras Presidency for the year 1883-84, (A 1272), Preserved at RAK, p. 7.

${ }^{46}$ Administration Report of the Public Works Department-Railway Branch-in the Madras Presidency for the year 1888-89, (A 1277), Preserved at RAK, p. 10.

${ }^{47}$ Administration Report of the Public Works Department-Railway Branch-in the Madras Presidency for the year 1889-90, (A 1278), Preserved at RAK, p. 10.

${ }^{48}$ Daniel R Headrick, Op.Cit., p.185.
} 

1891)

damage. Owing to the large amount of earthwork that was necessary to repair the breaches and the difficulty of obtaining labour during the Deepavali festival, this branch was not opened for traffic until $24^{\text {th }}$ November $1890^{49}$.

Along with the categorization of railway accidents in Madras Presidency during 1881 to 1891 , it is essential to look at the social base of injured and deceased in that misfortunes. The colonial documents and reports on the railway developments of Madras Presidency, do indicate that the deceased and injured were of three categories: passengers, servants of the Company and of the contractors and other persons. No passenger had killed, because of the 'causes beyond their control', during the period under discussion. Most of the injuries had happened due to the reasons beyond their control. It might have happened due to unexpected accidents inside the trains or in the premises of the railway stations. At the same time, some passengers were killed due to their own misconduct or for want of caution. The second category of persons injured or killed were the servants of the Company or of the contractors.

The colonial reports do mentions to them into two types: injured or killed due to causes beyond their control and injured or killed from their own misconduct or want of caution. The colonial records do mention that most of them had killed or injured due to their own misconduct or want of caution. But most of the accidents happened due to the absence of proper mechanisms for ensuring the safety of workers at the workplace. It is evident that the British might have given least priority to the safety of the menial workers. It is significant to note that no officers or persons of supervisory post found killed during the accidents ${ }^{50}$. The British railway companies' urge for maximizing profit prevented them from providing decent and secured work environment. Though their labour had been used extensively for the extension of Indian railways, the poor Indian labourers were not properly treated by the English. They were primarily driven by their commercial and capitalist interests. It is evident that "the Anglo-Indian merchants and the East-India trading houses in London saw railroads as a means of extending their business to inland towns" ${ }^{\prime 51}$. There was callous neglection of the safety and security of the workers. It is attested by the number of causalities happened during the time of the construction of railways in Madras Presidency.

Similarly, it is important to examine the death tolls due to suicides in the railway lines of Madras Presidency during the period from 1881 to 1891 . It makes clear that the number of suicides or attempts to suicides were comparatively higher. It is a strong indicator to the social tensions and social pressure on people to commit suicides. Train and railway lines were being identified as a mode to commit suicide. There was a public imagination of train as a single-eyed, smoke spitting, howling demon, which later became real demon when they killed people. The statistics from the administrative reports of Madras presidency show that the number of suicides and attempts to suicides had increased during the period under discussion. It is a clear indication that the socially alienated individuals and those who came under severe social pressure preferred to consider train tracks as their place of self-immolation. They had perceived the train as the demon and the railway lines as its legs to submit them finally and forever.

\section{CONCLUSION}

South India, of which Madras Presidency was the prime administrative component, had a rich history of frequent famines since 1729 and it intensified during 1878-79. In the years succeeded the region witnessed the evil effects of that prolonged instances of famines. Most of the poor village folk, who engaged in agrarian activities as workers, had lost everything. The climatic conditions too were quite adverse. In South India, there were a series of climatic changes occurred during mid $1870 \mathrm{~s}^{52}$ and

\footnotetext{
${ }^{49}$ Administration Report of the Public Works Department-Railway Branch-in the Madras Presidency for the year 1890-91, (A 1279), Preserved at RAK, p. 11.

${ }^{50}$ Administration Report of the Public Works Department-Railway Branch-in the Madras Presidency for the year 1883-84, (A 1272), Preserved at RAK, p. 7.

${ }^{51}$ Daniel R Headrick. (1981)The Tools of Empire: Technology and European Imperialism in the Nineteenth Century, Oxford University Press, New York and Oxford, p.182.

${ }^{52}$ South India had experienced a demographic crisis in the last quarter of the $19^{\text {th }}$ century. See Roland Lardinois, Famine, Epidemics and Mortality in South India: A Reappraisal of the Demographic Crisis of 1876-78 in Economic and Political Weekly (EPW), 20:11, 1985, pp.454.
} 

1891)

they had devastating effects on the commonfolk. Having faced of agrarian crisis, the life of agrarian folk in the region became quite miserable and they had been struggling to meet both ends of their lives. Along with famines, there were several epidemics. Such instances of epidemics too made the lives of the common people miserable ${ }^{53}$.

The people of upper castes and elites could survive such situations with the backing of social capital they acquired. But that was not the case of common people. The village folk lost their hope of leading a peace and happy life. They resorted to do suicides and trains and railway lines gave 'a speedy and faultless end' of their lives. To summarize, the train mishaps in Madras Presidency during the period under discussion had happened primarily capitalist urge to maximize profit. The greedy capitalist did not want to 'spare' their money for providing healthy work environment to the common labourers. There was the absence of proper protective measures at workspaces of railways and that compromised the lives of end number of common coolies. Their masters preferred to extend the Indian railway at the cost the 'lives unknown poor Indians', who could not find even a decent space in colonial records too. The climatic conditions and the situations of famines, and epidemics made the lives of the village folk into grim and they chose rail lines as their next way of ending life.

\section{REFERENCES}

[1] Bear,Laura. (2007).Lines of the Nation: Indian Railway Workers, Bureaucracy and the Intimate Historical Self, Columbia University Press, New York.

[2] Woolmer,Christian. (2009).Blood, Iron \& Gold: How the Railways Transformed the World, Atlantic Books, London.

[3] Pamphlet addressed to the Secretary of State for India, 1853, in Home Correspondence 'B', copies of letters sent, 1849-1879, L/PWD/2/68, OICC.

[4] Mukhopadhyay, Aparajita. (2018).Imperial Technology and Native Agency: A Social History of Railways in Colonial India, 1850-1920,Routledge, 2018.

[5] Arnold, David. (2013).Everyday Technology: Machines and the Making of India's Modernity, The University of Chicago Press, Chicago and London.

[6] Kerr,Ian J. (1997).Building the Railways of the Raj 1850-1900, Oxford University Press, Calcutta.

[7] Prasad,Amba. (1960). Indian Railways, Asia Publishing House, New Delhi.

[8] Robbins,M. (1962). The Railway Age, George Allen and Unwin Ltd., New Delhi.

[9] Menon,A Sreedhara. (1989). Modern India Since 1907 and History of the Freedom Movement, Thiruvananthapuram.

[10] Headrick,Daniel R. (1981).The Tools of Empire: Technology and European Imperialism in the Nineteenth Century, Oxford University Press, New York and Oxford.

[11] Kerr,Ian J. (2007).Engines of Change: The Railroads That Made India, Praeger Publishers, London.

[12] Arnold, David (2013).Everyday Technology: Machines and the Making of India's Modernity, The University of Chicago Press, Chicago and London.

[13] Manual of Administration-Madras Presidency-M/12, Preserved at Regional Archives, Kozhikode.

[14] G O No.1853 dated 28 November 1848, Public Works Department, Tamilnadu State Archives.

[15] Juland Danvers, Report to the Secretary of State For India In Council On Railways In India to the end of the year 1859, 1860. Accessed from www.google.com.au/books.

[16] G S Khosla. (1988).A History of Indian Railway, Govt. of India Publication, New Delhi.

[17] Ritika Prasad,Time Sense: Railways and Temporality in Colonial India, in Modern Asian Studies, Vol.47, Issue4, July 2013.

[18] Administration Report of the Public Works Department-Railway Branch-in the Madras Presidency for the year 1883-84, (A 1272), Preserved at Regional Archives, Kozhikode (RAK).

[19] Administration Report of the Public Works Department-Railway Branch-in the Madras Presidency for the year 1884-85, (A 1273), Preserved at RAK.

[20] Administration Report of the Public Works Department-Railway Branch-in the Madras Presidency for the year 1887-88, (A 1276), Preserved at RAK.

\footnotetext{
${ }^{53}$ Ira Klein, When the Rains Failed: Famine, Relief and Mortality in British India, in Indian Economic and Social History Review (IESHR), 26:4, 1989, p.201.
} 
Mishaps In/Front of the Iron Horse: A Social History of Train Accidents in Madras Presidency (18811891)

[21] Administration Report of the Public Works Department-Railway Branch-in the Madras Presidency for the year 1888-89, (A 1277), Preserved at RAK.

[22] Administration Report of the Public Works Department-Railway Branch-in the Madras Presidency for the year 1889-90, (A 1278), Preserved at RAK.

[23] Administration Report of the Public Works Department-Railway Branch-in the Madras Presidency for the year 1890-91, (A 1279), Preserved at RAK.

[24] Administration Report of the Public Works Department-Railway Branch-in the Madras Presidency for the year 1891-92, (A 1280), Preserved at RAK.

[25] Administration Report of the Public Works Department-Railway Branch-in the Madras Presidency for the year 1885-86, (A 1274), Preserved at RAK.

[26] Administration Report of the Public Works Department-Railway Branch-in the Madras Presidency for the year 1888-89, (A 1277), Preserved at RAK.

[27] Administration Report of the Public Works Department-Railway Branch-in the Madras Presidency for the year 1889-90, (A 1278), Preserved at RAK.

[28] Administration Report of the Public Works Department-Railway Branch-in the Madras Presidency for the year 1890-91, (A 1279), Preserved at RAK.

[29] Roland Lardinois, Famine, Epidemics and Mortality in South India: A Reappraisal of the Demographic Crisis of 1876-78 in Economic and Political Weekly (EPW), 20:11, 1985.

[30] Klein, Ira. (1989). When the Rains Failed: Famine, Relief and Mortality in British India, in Indian Economic and Social History Review (IESHR), 26:4.

\section{AUTHOR'S BIOGRAPHY}

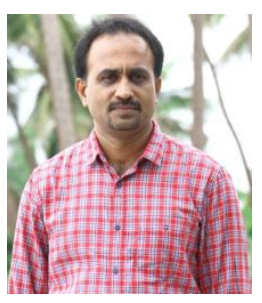

Jineesh $\mathbf{P}$ S, is Assistant Professor of History at Department of History, Government College, Madappally, affiliated to the University of Calicut, Kerala, India. His research includes Foucauldian theories, orality and literary, colonialism and technology transfer, circulatory practices in colonial India etc. He has presented research papers in various international and national conferences. His recent book is Kunjalimarakkar: Samaravum Sannidhyavum (DC Books, Kottayam, 2020). He is pursuing the Social History of Transportation Networks in Colonial Malabar for his doctoral dissertation.

Citation: JINEESH P S. "Mishaps In/Front of the Iron Horse: A Social History of Train Accidents in Madras Presidency (1881-1891)" International Journal of History and Cultural Studies (IJHCS). vol 7, no. 2, 2021, pp. 1-10. doi: DOI: https://doi.org/ 10.20431/2454-7654.0702001.

Copyright: (C) 2021 Authors. This is an open-access article distributed under the terms of the Creative Commons Attribution License, which permits unrestricted use, distribution, and reproduction in any medium, provided the original author and source are credited. 